\title{
EXAMINATION OF TOOTH SHADE IN RELATION TO AGE AND GENDER
}

\author{
Nenad Stošić, Jelena Popović, Jovanka Gašić, Aleksandar Mitić, \\ Marija Nikolić, Radomir Barac, Stefan Dačić \\ Department of Restorative Dentistry and Endodontics,Clinic of Dentistry, \\ Medical Faculty, University of Niš, Niš, Serbia
}

Summary. Physiological aging process leads to changes in all tissues and organs of the human organism. Changes of the tooth color with age occur as a result of the pulp chamber reduction and deposition of secondary dentine, when dentine become thicker and less transparent. The aim of this study was to determine degree of the tooth color change in relation to the age of patients and the gender. The study included 166 patients, aged from 18 to 77 years. All patients were divided into four age groups. Determination of the tooth color was performed by visual method using the Philips zoom shade guide chart in the middle third of the healthy upper central incisors. The results showed that $21,7 \%$ of the patients between 18-30 years had dominant light tooth color, $12.9 \%$ of the patients from 31-45 years had the medium color, and patients from 46-60 and older than 61 years in most cases had dark color of the teeth (9.1\% and $21 \%$ respectively). The dominant light tooth color was $A 2$, medium color A3, while the most common dark color was A3.5. Women had significantly lighter teeth compared to men. The study showed that younger patients had lighter teeth and that the color of teeth become darker with age.

Key words: tooth color, age, gender, upper central incisor.

\section{Introduction}

During the process of physiological aging, all tissues and organs of the human organism subject to change, as well as color of the teeth. From the aspect of forensic medicine, the color of teeth, as one of the morphological characteristics, can be of great importance in estimating the age of individuals (Aggarwal et al. 2008).

The color of the teeth depends on the thickness of the enamel, the dentine and the volume of the pulp chamber (Vivek et al. 2010). Each tooth shows the transition of different shades of colors from the incisal to the gingival third. Due to the close contact of the dentin with the enamel and its reduced thickness, the gingival third of the tooth is darker than the incisal. These color differences are related to the thickness and transparency of the enamel and dentine. In most cases, the caninus are darker than the central and lateral incisors (Hamed, 2014). The natural tooth color significantly changes with age. Young people have lighter teeth, especially in primary dentition. The color of the tooth becomes darker with age as a result of the formation of secondary dentin and the reduction of the pulp chamber (Morley, 1997). The change in color of the dentin, which thickness increases with age, is perceived through a thin layer of translucent enamel (Goodkind et al. 1987). The surface of the enamel during aging changes due to the exchange of ions in the oral environment (Goodkind et al. 1987). The studies have shown that there is a decrease in 
thickness of the enamel in the area of the cementoenamel junction with age, which is another factor contributing to tooth color change (Nanci, 2003).

The high aesthetic demands of patients have led to the development of different methods for determining the color of teeth. While the application of objective methods requires special conditions and apparatus, visual method is performed by comparing the tooth shade guide containing different nuances with the color of the teeth in the same environment under the same light (Gomez-Polo et al. 2015). Although the effectiveness of the visual method can be influenced by various factors that compromise results in color selection, (Ragain et al. 2000; Dozić et al. 2007), this method is the most common method for determining the color of teeth in everyday dental practice.

The aim of this study was to determine degree of the tooth color change in relation to the age of patients and the gender.

\section{Material and Method}

The research was conducted at the Department of Restorative Dentistry and Endodontic, Clinic of Dentistry, Medical Faculty, University of Niš, in period from February to May 2018.

One hundred and sixty-six patients ( 83 men and 83 women) aged from 18 to 77 years were included in this study. All patients were divided into four age groups:

I group: 18-30;

II group: 31-45;

III group: 46-60;

IV group: patients older than 61 years.

Table 1. Representation of patients by gender and age

Tabela 1. Zastupljenost pacijenta prema polu i starosti

\begin{tabular}{llllll}
\hline $\mathrm{N}(\%)$ & $18-30$ & $31-45$ & $46-60$ & $61-$ & $\sum$ \\
\hline $\mathrm{M}$ & $32(19.3 \%)$ & $17(10.25 \%)$ & $14(8.5 \%)$ & $20(12 \%)$ & $83(50 \%)$ \\
$\mathrm{F}$ & $34(20.5 \%)$ & $17(10.25 \%)$ & $12(7.2 \%)$ & $20(12 \%)$ & $83(50 \%)$ \\
\hline$\sum$ & 66 & 34 & 26 & 40 & 166 \\
\hline
\end{tabular}

The research was performed on the healthy upper central incisors. Only natural, unrestored teeth, with no pathological discolorations, were included in this study. Teeth with white spots in the middle third of the labial surface, or with bleaching treatments in their history were excluded from the study. Before measurements, the labial surface of each tooth was cleaned using polishing brush and paste. Afterwards, every participant thoroughly rinsed with water.

Each tooth was observed for 4-5 seconds. All the observations were made in natural light using a Philips zoom shade guide in the middle third of the labial surface of the teeth (Figure 1). In order to avoid general variables such as external light conditions, experience, age and fatigue of the human eye which can lead to inconsistencies and bias, all of the measurements were performed by one researcher. In order to obtain clearer results, the shades on the guide were divided into three groups: light, medium colors and dark. Statistical analysis was used to find correlations between age and enamel color. 
Statistical analysis was performed using $\chi^{2}$ test. A p value less than 0.05 was considered as statistically significant.

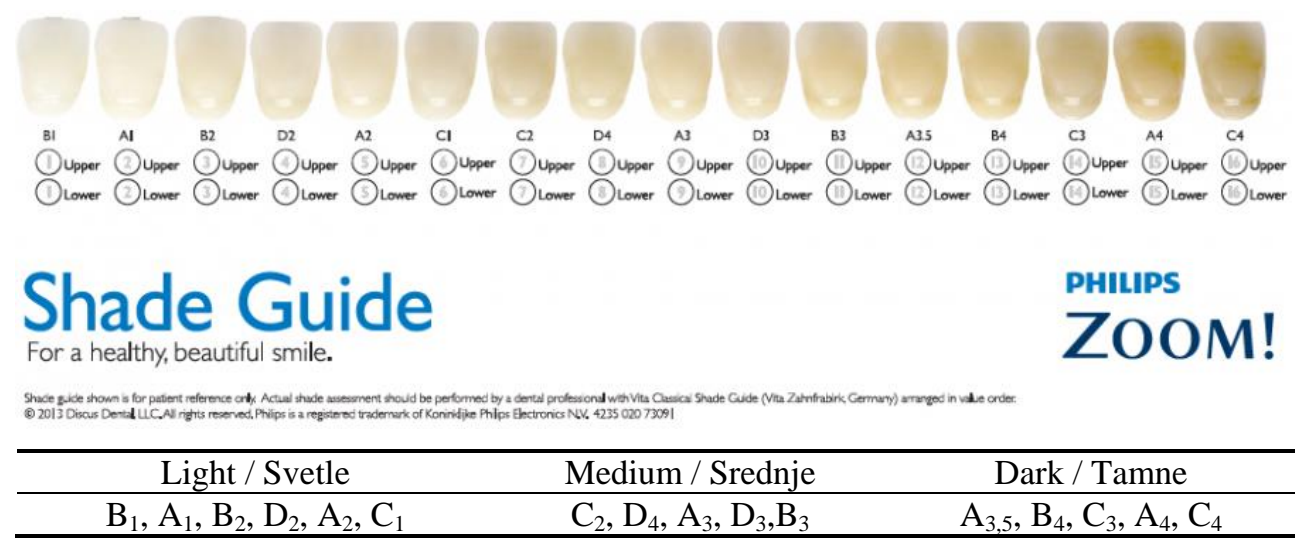

Figure 1. Tooth shade guide used in the study

Slika 1. Ključ boja korišćen u studiji

\section{Results}

The results showed that $21.7 \%$ of the patients from the I group, had a light tooth color (the most common was A2), $14.4 \%$ of the patients from the same age group had a medium color (the most common was A3) while only 3.6\% had dark tooth color (the most common was B4). In the II group, $12.9 \%$ of the patients had a medium tooth color, among which the A3 dominates. The light tooth color was represented at $6.6 \%$ patients (the most common were $\mathrm{A} 2$ and $\mathrm{C} 1$ ) while dark color was noticed in only $2.4 \%$ of patients (the most common was A3.5). The dark color of the teeth was observed in $9.6 \%$ of patients from the III group (the most frequent was A3.5), the medium tooth color such as A3 was present in $6.6 \%$. In IV group of patients, a significantly higher presence of dark tooth color was found in $21 \%$ (the most frequent was A3.5). The medium tooth color was present in $3 \%$ of patients (the most common was B3). By examining the representation of tooth color by gender, A2 was the most common light tooth color in both gender with $16.6 \%$ (7.6\% in males and $9 \%$ in females). The most common medium tooth color was A3 $(11.4 \%$ in males and $12 \%$ in females). The most commonly observed dark tooth color was A3.5 (11.5\% in males and 9\% in females) (Table 2).

Table 3 shows the distribution of tooth color by age between male and female. By comparison of the tooth color in each category, there was no statistically significant difference in relation to the gender and age group: light tooth color category $\left(\chi^{2}=0.062\right.$; $\mathrm{p}=0.802)$, medium tooth color category $\left(\chi^{2}=3.542 ; \mathrm{p}=0.3015\right)$ and dark tooth color category $\left(\chi^{2}=1.868 ; \mathrm{p}=0.600\right)$. 
Table 2. Distribution of the tooth color in male and female

Tabela 2. Zastupljenost boje zuba kod muškaraca $i$ žena

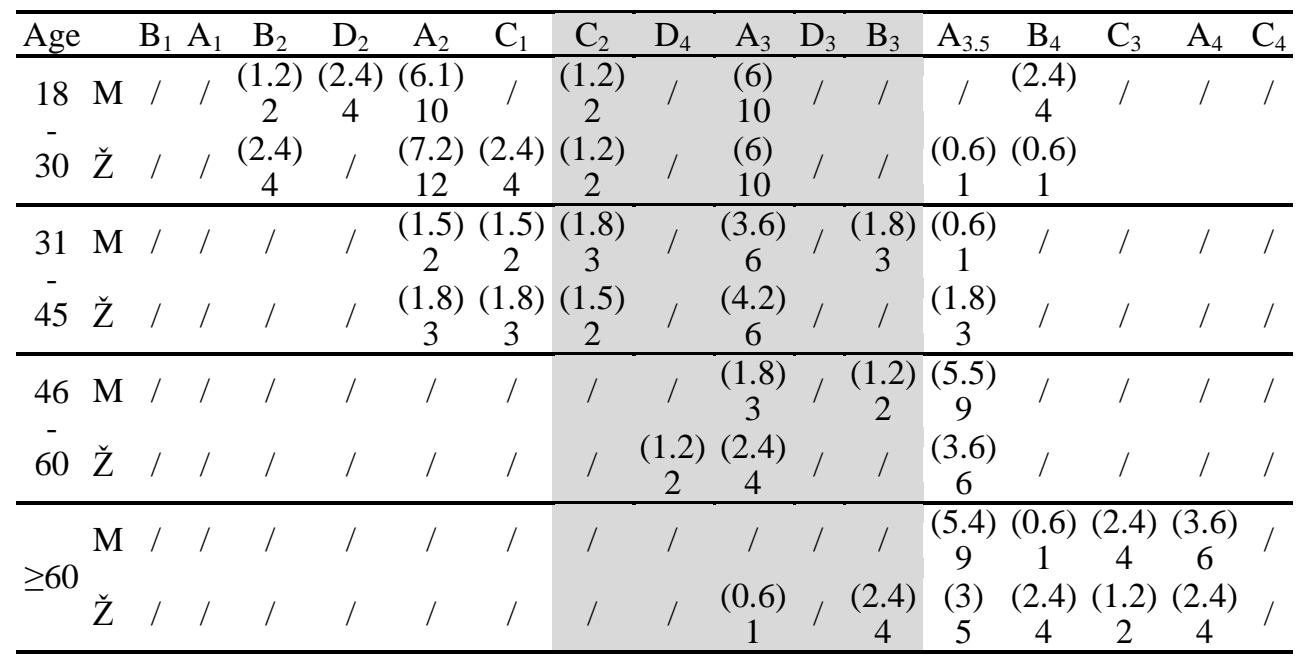

Table 3. Distribution of the color in the category of tooth color by gender and age group Tabela 3. Distribucija boje u okviru kategorije boje zuba prema polu i starosnoj grupi

\begin{tabular}{ccccc}
\hline Age group & & Lighter & Medium & Dark \\
\hline \multirow{2}{*}{$18-30$} & $\mathrm{M}$ & 16 & 12 & 4 \\
& $\mathrm{~F}$ & 20 & 12 & 2 \\
\hline \multirow{2}{*}{$34-45$} & $\mathrm{M}$ & 4 & 12 & 1 \\
& $\mathrm{~F}$ & 6 & 8 & 3 \\
\hline \multirow{2}{*}{$46-60$} & $\mathrm{M}$ & 0 & 5 & 6 \\
& $\mathrm{~F}$ & 0 & 6 & 20 \\
& $\mathrm{M}$ & 0 & 0 & 16 \\
\hline \multirow{2}{*}{$\geq 60$} & $\mathrm{~F}$ & 0 & 5 & 1.868 \\
& & 0.062 & 3.542 & 0.600 \\
\hline
\end{tabular}

Table 4. Distribution of tooth color in the age group by gender

Tabela 4. Distribucija boje zuba u okviru starosne grupe prema polu

\begin{tabular}{|c|c|c|c|c|c|c|}
\hline Age group & & Lighter & Medium & Dark & $\chi^{2}$ & $\mathrm{p}$ \\
\hline \multirow{2}{*}{$18-30$} & $\mathrm{~m}$ & 16 & 12 & 4 & \multirow{2}{*}{0.624} & \multirow{2}{*}{0.732} \\
\hline & $\mathrm{f}$ & 20 & 12 & 2 & & \\
\hline \multirow{2}{*}{$34-45$} & $\mathrm{~m}$ & 4 & 12 & 1 & \multirow{2}{*}{2.2} & \multirow{2}{*}{0.332} \\
\hline & $\mathrm{f}$ & 6 & 8 & 3 & & \\
\hline \multirow{2}{*}{$46-60$} & $\mathrm{~m}$ & 0 & 5 & 9 & \multirow{2}{*}{0.047} & \multirow{2}{*}{0.827} \\
\hline & $\mathrm{f}$ & 0 & 6 & 6 & & \\
\hline \multirow{2}{*}{$\geq 60$} & $\mathrm{~m}$ & 0 & 0 & 20 & \multirow{2}{*}{3.111} & \multirow{2}{*}{0.778} \\
\hline & f & 0 & 5 & 16 & & \\
\hline
\end{tabular}


Table 4 shows a comparison between the tooth colors among each age category. No statistically significant difference was found in color distribution in any age category: a category of $18-30$ years $\left(\chi^{2}=0.624 ; p=0.732\right)$; a category of 34-45 years $\left(\chi^{2}=2.2 ; p=0.332\right)$; $46-60$ years $\left(\chi^{2}=0.047 ; p=0.827\right)$, category of $\geq 60$ years $\left(\chi^{2}=3.111 ; p=0.778\right)$.

Table 5. Distribution of tooth color by age group Tabela 5. Distribucija boje zuba prema starosnim grupama

\begin{tabular}{cccccc}
\hline Age group & Lighter & Medium & Dark & $\chi^{2}$ & $p$ \\
\hline $18-30$ & 36 & 24 & 6 & & \\
$34-45$ & 10 & 20 & 4 & 94.316 & $<0.001$ \\
$46-60$ & 0 & 11 & 15 & & \\
$\geq 60$ & 0 & 5 & 36 & & \\
\hline
\end{tabular}

A statistically significant difference was observed in the distribution of tooth color in relation to age groups $\left(\chi^{2}=94.316 ; \mathrm{p}<0.001\right)$. The light tooth color, as well as the medium tooth color, were more common determined in young people, while the dark tooth color was significantly more present among the elderly (Table 5).

\section{Discussion}

Although there are many different methods that are currently used to assess tooth color, the visual method represents the most frequent method for tooth color assesment in everyday dental practice (Regain et al. 2000; Dozić et al. 2007, Hugo et al. 2005). It is used for determination of the tooth color for conservative aesthetic restorations as well as to adjust the color of the teeth during prosthetic treatment. Dental shade guides contain a limited selection of compared colors. This method varies, depending on the clinician's percepcion, experiences, ambient light condition and from shade guide used (Dozić et al. 2007; Hammad, 2003; Okubo et al. 1998). The use of visual method is a quick and costeffective method for measuring tooth color. In the present study tooth color changes were assessed using a dental shade guide. During the implementation of this method, the tooth color is determine by comparing the shade guide, which contains different colors, with the color of the teeth in the same environment under the same light (Gómez-Polo et al. 2015).

The color of the teeth is determined by a combination of intrinsic and extrinsic factors (Watts et al. 2001). Intrinsic factors default the light absorption and scattering properties of the enamel and dentine (van der Burgt et al. 1990). Extrinsic factors are connected with absorption of different matters (e.g. tea, red wine, chlorhexidine, iron salts) on the surface of enamel (Joiner, 2004). Since the teeth do not have a uniform color along their entire surface, the tooth colour in the present study was determined in the middle third of the labial side. The middle third of the teeth is generally described as the place that has the best representation of the tooth color, because the color range is changed from the incisal to the gingival area (Goodkind et al. 1987; Mayekar, 2001; Okubo et al. 1998). This is because the incisal third of the tooth is often translucent and the gingival third is modified by the surrounding tissue of the gingiva (O’Brien et al. 1997; Schwabacher et al. 1994; Hasegawa et al. 2000). The representation of different nuances of colors in different areas of the tooth is described by many authors (Rosenstiel et al. 2006; Winkler et al. 2006). The color of the tooth also depends on the thickness of the enamel and dentine, and the volume of the pulp chamber (Vivek et al. 2010). Because of that, in most of cases, canines are darker than central and lateral incisors (Hamed, 2014). 
The results of this study showed that there were no statistically significant differences in the color of the teeth between men and women in any of the age groups. These results are in accordance with the results of the same type of teeth obtained in various studies (Al-Saleh et al. 2007; Jahangiri et al. 2002; Hasegawa et al. 2000). However, in the study of GozaloDiaz et al. (2008) tooth shade guide has been used for color matching and they showed that there was a significant difference between the gender and the tooth color. Odioso et al. (1999) performed a study on the population of 180 people from the United States and showed that women had a statistically significant lighter tooth color of the upper central incisors compared to men. The reason for the variation in the study results could be due to the different shade matching system used (Gozalo-Diaz et al. 2008; Odioso et al. 1999). In the study of Karaman et al. (2017) conducted on 202 patients, categorized in four age groups, was found that $\mathrm{A} 2$ is the most common light tooth color in both gender $(23.6 \%$ in males and $34.5 \%$ in females). The results of this research completely support these statements.

Color is one of the most important determinants of dental esthetics which can be of great significance in estimating age of an individual. Many studies have shown that young people have lighter teeth (Juszczyk et al. 2009; Odioso et al. 2009; Jahangiri et al. 2002; Goodkind et al. 1987; Zhao et al. 1998). The natural tooth color has a tendency to change with the age which is the result of a large number of factors (Goodkind et al. 1987; Mayekar, 2001). The color of the tooth becomes darker and more yellow with age because of the fact that dental pulp shrinks and the dentin layer becomes thick due to deposition of secondary dentine. The surrounding dentine becomes harder and less permeable (Morley, 1997).

The results of this study also showed that the most common light tooth color was A2, A3 was dominant in the group of the middle nuances, while the most common dark color of the tooth was A3.5. These results correlate with the representation of teeth colors according to age groups observed in the study Karaman et al. (2017).

Subjective choice of natural tooth color may be made more systematic and ordered by performing a visual comparison with the most frequent shade guide according to age and gender group. It would be advisable to carry out longitudinal studies and spectral measurements on representative samples at different moments, with different ethnic categories and similar age groups. Knowledge of the distribution of natural tooth shades according to age group and gender may be a useful in shade selection, particularly for inexperienced operators.

\section{Conclusion}

During examination the overall distribution of tooth color in relation to the gender and age of patients, it was found that A2 was the most common light tooth color, the most common medium nuance was A3, while the most common dark color was A3.5. The study showed that women had lighter tooth color compared to men, that younger patients had a lighter teeth, and that the color of teeth become darker with age.

Acknowledgement: This work has been supported by the grant No. 41018 of the Serbian Ministry of Science. 


\section{References}

Aggarwal, P., Suxena, S., Bansal, P. (2008). Incremental lines in root cementum of human teeth: an approach to their role in age estimation usin polarising microscopy. Indian J dent Res, 19,119-127.

Al-Saleh, S., Tashkandi, E. (2007). Three-dimensional color coordinates of natural teeth in a sample of young saudis: A pilot study. Saudi Dental Journal, 19, 97-100.

Dozić, A., Kleverlaan, CJ., El-Zohairy, A., Feilzer, AJ., Khashayar, G. (2007). Performance of five commercially available tooth color-measuring devices. Journal of Prosthodontics, 16, 93-100.

Goodkind, RJ., Keenan, K., Schwabacher, WB. (1987) Use of a fiberoptic colorimeter for an in vivo color measurement of 2830 anterior teeth. Journal of Prosthetic Dentistry, 58, 535-542.

Gómez-Polo, C., Gómez-Polo, M., Celemín Viñuela, A, Martínez Vázquez de Parga JA. (2015).A clinical study relating CIELCH coordinates to the color dimensions of the 3D-Master System in a Spanish population. J Prosthet Dent, 113, 185-90.

Gozalo-Diaz, D., Johnston, WM., Wee, AG. (2008). Estimating the color of maxillary central incisors based on age and gender. The Journal of prosthetic dentistry, 100, 93-98.

Hamed, M., Maryam, B., Amin, K. (2014) Colors in tooth discoloration: A new classification and literature rewiew. International Journal of Clinical Dentistry, 7, 16-28.

Hammad, IA. (2003). Intrarater repeatability of shade selections with two shade guides. The Journal of prosthetic dentistry, $89,50-53$.

Hasegawa, A., Motonomi, A., Ikeda, I., Kawaguchi, S. (2000). Color of natural tooth crown in Japanese people. Color Research and Application, 25, 43-48.

Hugo, B., Witzel, T., Klaiber, B. (2005). Comparison of in vivo visual and computer-aided tooth shade determination. Clinical Oral Investigations, 9, 244-250.

Jahangiri, L., Reinhardt, SB., Mehra, RV., Matheson, PB. (2002). Relationship between tooth shade value and skin color: an observational study. Journal of Prosthetic Dentistry, 87, 149-152.

Joiner, A. (2004). Tooth colour: A review of the literature. J Dent, 32 Suppl 1, 3-12.

Juszczyk, A.,Clark, R.,Radford, D. (2009). Do dentists communicate well with dental technicians? Vital, 6, 32-34.

Karaman, T., Altintas, E., Eser, B., Faruk O, TTT., Bozoglan, A. (2017). Evaluation of the maxillary anterior teeth color distribution according to age and gender with Spectrophotometer.

Mayekar, SM. Shades of a color illusion or reality? (2001). Dental Clinics of North America, 45, 155-172.

Morley, J. (1997). The esthetics of anterior tooth aging. Current Opinion in Cosmetic Dentistry, 4, 35-39.

Nanci, A. 2003. Tencate's oral histology: development, structure and function. 6th Ed.

Odioso, L., Gibb, R., Gerlach, R. (1999). Impact of demographic, behavioral, and dental care utilization parameters on tooth color and personal satisfaction. Compendium of continuing education in dentistry (Jamesburg, NJ: 1995), Supplement. (29), S35-41; quiz S43.

Okubo, SR., Kanawati, A., Richards, MW., Childress, S. (1998).Evaluation of visual and instrument shade matching. Journal of Prosthetic Dentistry, 80, 642-648.

O’Brien, WJ., Hemmendinger, H., Boenke, KM., Linger, JB., Groh, CL. (1997). Color distribution of three regions of extracted humanteeth. Dental Materials, 13, 179-185.

Ragain, JC Jr, Johnston, WM. (2000). Color acceptance of direct dental restorative materials by human observers. Color Res Appl, 25, 278-85.

Rosenstiel, SF., Land, MF., Fujimoto, J. (2006). Contemporary fixed prosthodontics. Elsevier Health Sciences.

Schwabacher, WB., Goodkind, RJ., Lua, MJR. (1994). Interdependence of the hue, value, and chroma in the middle site of anterior human teeth. Journal of Prosthodontics, 3, 188-192.

van der Burgt, TP., ten Bosch, JJ., Borsboom, PC., Kortsmit, WJ. (1990). A comparison of new and conventional methods for quantification of tooth color. J Prosthet Dent, 63, 155-62.

Vivek, S., Preeti, S., Ramandeep, S., Dalibir, S. (2010). Role of Enamel Colour in Age Estimation Using a Dental Shade Guide: A Study in the Triciti Region a Chandigarh, Mohaliand Panchkula. J Punjab Acab Forensic Med Toxicol, 10, 76-78.

Watts A, Addy M. (2001). Tooth discolouration and staining: a reviewof the literature. British Dental Journal, 190, 309-316. 
Winkler, S., Boberick, KG., Weitz, KS., Datikashvili, I., Wood, R. (2006). Shade matching by dental students. Journal of Oral Implantology, 32, 256-258.

Zhao, Y., Zhu, J. (1998) In vivo color measurement of 410 maxillary anterior teeth. The Chinese Journal of Dental Research, 3, 49-51.

\section{ISPITIVANJE RAZLIKA U BOJI ZUBA U ODNOSU NA STAROST I POL}

\section{Nenad Stošić, Jelena Popović, Jovanka Gašić, Aleksandar Mitić, Marija Nikolić, Radomir Barac, Stefan Dačić}

Sažetak. U toku fiziološkog procesa starenja dolazi do promena na svim tkivima i organima ljudskog organizma. Promena boje zuba sa starošću nastaje kao posledica redukcije pulpne komore i stvaranja sekudarnog dentina koji postaje deblji i manje transparentan. Cilj istraživanja je bio da se utvrdi stepen promene boje zuba sa starošću pacijenata i u odnosu na pol. Istraživanjem je obuhvaćeno 166 pacijenata (83 muškaraca i 83 žene) starosti od 18 do 77 godina. Svi pacijenti bili su podeljeni u četiri starosne grupe. Studija je sprovedena na zdravim gornjim centalnim sekutićima. Određivanje boje zuba izvršeno je vizuelnom metodom korišćenjem ključa za boju Philips zoom shade guide u srednjoj trećini krunice zuba. Rezultati su pokazali da je u starosnoj grupi od 18-30 godina dominirala svetla boja zuba sa $21,7 \%$, u grupi od $31-45$ godina srednja nijansa sa $12,9 \%$ i u starosnim grupama od 46-60 i starijih od 61 godine ustanovljena je tamna boja zuba sa $9,1 \%$ odnosno $21 \%$. Najčešća svetla boja zuba bila je A2, najzastupljenija među srednjim nijansama je bila $A 3$, dok je najčešća tamna boja zuba bila $A 3,5$. Žene su imale znatno svetliju boju zuba u poređenju sa muškarcima. Istraživanje je pokazalo da su pacijenti mlađeg uzrasta imali svetlije zube i da boja zuba sa godinama starosti postaje tamnija.

Ključne reči: boja zuba, starenje, pol, gornji centralni sekutić. 